\title{
On Cartesian products with small crossing numbers
}

\author{
MARIÁN KLEŠČ and JANA PETRILlOVÁ
}

\section{ABSTRACT.}

Kulli at al. started to characterize line graphs with crossing number one. In this paper, the similar problems were solved for the Cartesian products of two graphs. The necessary and sufficient conditions are given for all pairs of graphs $G_{1}$ and $G_{2}$ for which the crossing number of their Cartesian product $G_{1} \times G_{2}$ is one or two.

DEPARTMENT OF MATHEMATICS AND THEORETICAL INFORMATICS

TECHNICAL UNIVERSITY OF KOŠICE

KOŠICE, SLOVAKIA

E-mail address: marian.klesc@tuke.sk

E-mail address: jana.petrillova@tuke.sk

Received: 31.10.2010; In revised form: 30.06.2011; Accepted: 30.11.2011 